\title{
Candidate SNP markers of aggressiveness- related complications and comorbidities of genetic diseases are predicted by a significant change in the affinity of TATA- binding protein for human gene promoters
}

Irina V. Chadaeva ${ }^{1,2}$, Mikhail P. Ponomarenko ${ }^{1,2^{*}}$, Dmitry A. Rasskazov', Ekaterina B. Sharypova', Elena V. Kashina ${ }^{1}$, Marina Yu Matveeva ${ }^{1}$, Tatjana V. Arshinova', Petr M. Ponomarenko ${ }^{3}$, Olga V. Arkova ${ }^{1,4}$, Natalia P. Bondar ${ }^{1}$, Ludmila K. Savinkova ${ }^{1}$ and Nikolay A. Kolchanov ${ }^{1,2}$

From The International Conference on Bioinformatics of Genome Regulation and StructurelSystems Biology (BGRSISB-2016) Novosibirsk, Russia. 29 August-2 September 2016

\begin{abstract}
Background: Aggressiveness in humans is a hereditary behavioral trait that mobilizes all systems of the body—first of all, the nervous and endocrine systems, and then the respiratory, vascular, muscular, and others-e.g., for the defense of oneself, children, family, shelter, territory, and other possessions as well as personal interests. The level of aggressiveness of a person determines many other characteristics of quality of life and lifespan, acting as a stress factor. Aggressive behavior depends on many parameters such as age, gender, diseases and treatment, diet, and environmental conditions. Among them, genetic factors are believed to be the main parameters that are well-studied at the factual level, but in actuality, genome-wide studies of aggressive behavior appeared relatively recently. One of the biggest projects of the modern science-1000 Genomes-involves identification of single nucleotide polymorphisms (SNPs), i.e., differences of individual genomes from the reference genome. SNPs can be associated with hereditary diseases, their complications, comorbidities, and responses to stress or a drug. Clinical comparisons between cohorts of patients and healthy volunteers (as a control) allow for identifying SNPs whose allele frequencies significantly separate them from one another as markers of the above conditions. Computerbased preliminary analysis of millions of SNPs detected by the 1000 Genomes project can accelerate clinical search for SNP markers due to preliminary whole-genome search for the most meaningful candidate SNP markers and discarding of neutral and poorly substantiated SNPs.

(Continued on next page)
\end{abstract}

\footnotetext{
* Correspondence: pon@bionet.nsc.ru

${ }^{1}$ Institute of Cytology and Genetics, Siberian Branch of Russian Academy of

Sciences, 10 Lavrentyev Avenue, Novosibirsk 630090, Russia

${ }^{2}$ Novosibirsk State University, 2 Pirogova Street, Novosibirsk 630090, Russia

Full list of author information is available at the end of the article
} 
(Continued from previous page)

Results: Here, we combine two computer-based search methods for SNPs (that alter gene expression) \{i\} Web service SNP_TATA_Comparator (DNA sequence analysis) and \{ii\} PubMed-based manual search for articles on aggressiveness using heuristic keywords. Near the known binding sites for TATA-binding protein (TBP) in human gene promoters, we found aggressiveness-related candidate SNP markers, including rs1143627 (associated with higher aggressiveness in patients undergoing cytokine immunotherapy), rs544850971 (higher aggressiveness in old women taking lipid-lowering medication), and rs10895068 (childhood aggressiveness-related obesity in adolescence with cardiovascular complications in adulthood).

Conclusions: After validation of these candidate markers by clinical protocols, these SNPs may become useful for physicians (may help to improve treatment of patients) and for the general population (a lifestyle choice preventing aggressiveness-related complications).

Keywords: Aggressiveness, Gene, Promoter, TATA-binding protein, Single nucleotide polymorphism, Candidate SNP marker, Keyword-based search, Prediction in silico

\section{Background}

Ethologists define aggressive behavior as a hereditary behavioral pattern performing functions that are important for preservation of the species, namely, defense of the territory, progeny, and shelter and establishment of social-hierarchical relationships within society [1]. Moreover, in many species of animals, low aggressiveness leads to decreased fitness of an individual in particular and problems with reproduction of a population in general [2]. Nonetheless, the opposite extreme-increased aggression among animals of the same species-also has negative consequences, for example, infanticide. In social species of animals, the main mechanism that controls aggressiveness and restrains it within optimal limits is the hierarchical structure of relationships in society. Thus, aggressive behavior has adaptive nature, and its reaction norm is fixed by natural selection [2]. On the other hand, in modern human society, uncontrolled manifestation of aggression is becoming a leading social problem [3-5]. Researchers of aggressive behavior in people classify aggression into several types, which include the impulsive type (caused by external stimuli) and the pathological type [6]. The latter is a symptom of some affective and anxiety disorders. Nonetheless, expression of aggressiveness in real actions of an individual does not depend on its primary causes and manifests itself as physical or verbal aggression [7]. As shown in many experiments on selection for aggressive behavior [8], the latter is an inherited trait, whose phenotypic variability is also influenced by genetic factors [9]. In addition, environmental factors and endogenous ones are so tightly inter-related that research into aggressive human behavior unites the efforts of clinicians, pharmacists, physiologists, geneticists, psychologists, bioinformaticians, pedagogues, sociologists, legal scholars, economists, and other relevant experts, e.g., specialists on insurance, management, health care, law enforcement, and environmental protection. Despite the large number of studies on human aggressiveness, specific genes determining this type of behavior have not been identified to date. The complexity of the problem stems from multifactorial neuroendocrine physiological regulatory mechanisms that are based on genetic systems such as epigenetic regulation of aggressive behavior. For this reason, genome-wide studies of this vitally important form of human behavior are only at the rudimentary stage (e.g., [10]).

One of the biggest modern scientific projects -1000 Genomes [11]-involves identification of SNPs on the whole-genome scale and storing them in the dbSNP database [12], which is an integral part of the reference human genome, which represents the ancestral alleles of all SNPs and, thus, is constantly refined. Taken together with others public parts of the reference human genome such as the Ensembl database [13] and the Web service UCSC Genome Browser [14], dbSNP allows investigators to design, for instance, experiments on gene knockouts in animals designed for research on phenotypic consequences of SNPs as well as for detection of perturbations of gene networks during disorders and under the influence of therapeutic strategies [15].

Biomedical SNP markers represent differences between an individual human genome and the reference human genome; these markers can help to improve a medical treatment [16], to prevent complications of a treatment [17], and to predict comorbidities within the framework of postgenomic predictive preventive personalized medicine [18]. Clinical comparison between cohorts of patients with a given disease and healthy volunteers (as a control) allows researchers to identify SNPs whose allele frequencies significantly separate them from one another as the markers of the above condition (e.g., see [19]). Computer-based analysis of hundreds of millions of unannotated SNPs identified by the 1000 Genomes project [11] may accelerate the clinical search for biomedical SNP markers [20, 21]. Many Web services [22-39] facilitate the bioinformatic search 
for candidate SNP markers in terms of ranking of unannotated SNPs by their similarity to biomedical SNP markers. These tools take into account whole-genome maps of genes [13, 14], protein-binding sites, interchromosomal contacts, nucleosomes, and transcripts either in health [40], during infection [41] (or other disease [42]), or after treatment [43]. According to the Central Limit Theorem, the accuracy of this similarity-based search for candidate SNP markers increases with the increase in the number of genome-wide maps [44].

Within this mainstream approach, SNPs located in protein-coding gene regions [45] seem to be more informative in the case of monogenic diseases because of the invariant types of disruption in both structure and function of the altered protein [46], whereas SNPs located in regulatory gene regions appear to be more likely to be associated with polygenic treats and disorders, e.g., aggressiveness. With this in mind, the regulatory SNPs in binding sites for TATA-binding protein (TBP) seem to be best studied due to their fixed locations within the narrow region $[-70 ;-20]$ upstream of the transcription start sites of protein-coding genes in the human genome $[47,48]$. Because model animals with a null-mutation [49] or a knockdown of TBP [50] are always inviable, SNPs in TBP-binding sites may be vital and, thus, most promising for computer-based predictions of candidate SNP markers of polygenic treats such as aggressiveness in this study.

Earlier, we developed the public Web service SNP_TATA_Comparator (http://beehive.bionet.nsc.ru/cgi-bin/mgs/ tatascan/start.pl) [51, 52] for estimation of the statistical significance (Fisher's Z-score) of the difference between ancestral and minor SNP variants of a given TBP-binding site in terms of the expression change of the gene whose promoter contains this site [53]. This estimation was explored in detail by our experiments in vitro under both equilibrium [54] and nonequilibrium [55] conditions of the electrophoretic mobility shift assay (EMSA). Furthermore, we verified these estimates using two modern tools of real-time assays, such as a ProteOn ${ }^{\text {tu }}$ XPR36 biosensor (Bio-Rad Lab) [56] and an SX.20 spectrometer (Applied Photophysics) [57]. In addition, we tested these estimates using independent data of over 100 experiments by others [58-65]. That is why we apply this approach to studies of unannotated SNPs detected by the 1000 Genomes project [11] which are less known at present. Recently, we predicted candidate SNP markers of complications of hereditary diseases in obesity [66], of autoimmune comorbidities of these diseases [67], and of circadian rhythm disorders [68].

In the present work, we extended the use of our Web service $[51,52]$ to unannotated SNPs near known SNP markers of monogenic diseases in TBP-binding sites of human gene promoters. Among them, we selected candidate SNP markers of aggressiveness-related complications of these diseases. After validation of these candidate markers by clinical protocols, these SNPs may become useful for physicians (i.e., may help them to improve treatment of patients) and for the general population (e.g., may help to choose a lifestyle preventing aggressiveness-related comorbidities and complications) within the framework of postgenomic predictive preventive personalized medicine [18].

\section{Results}

Tables 1, 2, 3, and 4 show the results obtained using our Web service SNP_TATA_Comparator $[51,52]$ for the 68 biomedical and candidate SNP markers in the TBPbinding sites of human gene promoters [52] (see Methods: Additional file 1: Supplementary Method). Let us first review in more detail only one human gene in order to briefly describe all the others.

\section{Candidate SNP markers of aggressiveness as an adverse effect of medical treatments}

The human GH1 gene (growth hormone 1, synonym: somatotropin) contains a biomedical SNP marker (rs11568827) of short stature [69]. According to the results of electrophoretic mobility shift assay (EMSA) [69], this SNP reduces this gene's expression because it damages the binding site for an unknown transcription factor rather than the TBP-binding site (Table 1 . The prediction of our Web service $[51,52]$ was consistent with these independent experimental data (Fig. 1a: text box "Results", line "Decision" contains the label "insignificant").

First, using the primary keyword search (hereinafter: see Methods, Additional file 2: Figure S1: two boxes outlined with a dashed line), we found the retrospective clinical review [70] showing that a GH1 deficiency is a biochemical marker of lesser aggression of mentally unstable patients during growth hormone treatment when the dose of the additional lithium (Li)-based or others antiaggression medication may be reduced). Next, using the secondary keyword search (hereinafter: see Methods: Additional file 2: Figure S1: one box outlined with a dotted line), we found the retrospective and clinical case reviews indicating that short stature and aggressiveness coexist in Smith-Magenis syndrome [71, 72], Dubowitz syndrome [73], and Floating-Harbor syndrome [74]. In addition, women of constitutionally short stature are more aggressive than the ones with Turner syndrome [75]. In contrast, children and adolescents with hypopituitarism have short stature and show a tendency to avoid aggression.

On the basis of all the above reasons together with our recent hypothesis on "how SNP may change the apparent biological activity of drugs inhibiting target genes" [76], we propose rs11568827 as a candidate SNP marker associated with a lesser dose of an additional antiaggression 
Table 1 Candidate SNP markers of aggressiveness as an adverse effect of medical treatments (these markers may change the TBP-promoter affinity)

\begin{tabular}{|c|c|c|c|c|c|c|c|c|c|c|}
\hline \multirow[t]{2}{*}{ Gene } & \multirow{2}{*}{$\begin{array}{l}\text { dbSNP [12] } \\
\text { or see } \\
\text { [Reference] }\end{array}$} & \multirow[t]{2}{*}{$5^{\prime}$ flank } & \multirow[t]{2}{*}{$\frac{\mathrm{wt}}{\mathrm{mut}}$} & \multirow[t]{2}{*}{ 3' flank } & \multicolumn{2}{|c|}{$\mathrm{K}_{\mathrm{D}}, \mathrm{nM}$} & \multicolumn{2}{|c|}{ Z-score } & \multirow{2}{*}{$\begin{array}{l}\text { Known diseases (observations) [Reference] or hypothetical } \\
\text { ones in the case of the candidate SNP markers predicted } \\
\text { by us in [this work] (see Methods: Additional file 2: Figure S1) }\end{array}$} & \multirow{2}{*}{$\begin{array}{l}\text { [Ref] or [this } \\
\text { work] }\end{array}$} \\
\hline & & & & & $\frac{\overline{w t}}{m u t}$ & $\bar{\Delta}$ & $\bar{z}$ & $a$ & & \\
\hline \multirow[t]{6}{*}{$\overline{\mathrm{GH} 1}$} & rs11568827 & aggggccagg & $\underline{\mathrm{g}}$ & tataaaaagg & $\frac{1.5}{1.4}$ & $=$ & 1 & - & $\begin{array}{l}\text { Short stature (unknown TF-binding site damaged rather } \\
\text { than TATA box) }\end{array}$ & [69] \\
\hline & rs796237787 & gaaggggcca & $\underline{\mathrm{g}}$ & ggtataaaaa & $\frac{1.5}{1.4}$ & $=$ & 1 & - & \multirow{3}{*}{$\begin{array}{l}\text { (hypothetically) low aggression of patients during growth } \\
\text { hormone treatment (case review); short stature and } \\
\text { aggressiveness co-exist in Smith-Magenis syndrome, } \\
\text { Dubowitz syndrome, Floating-Harbor syndrome; and } \\
\text { females with constitutional short stature are more } \\
\text { aggressive than the ones with Turner syndrome; children } \\
\text { and adolescents with hypopituitarism have short stature } \\
\text { and show a tendency to avoid aggressiveness } \\
\text { (case reviews) }\end{array}$} & \multirow{3}{*}{$\begin{array}{l}\text { [this work] } \\
{[70-75]}\end{array}$} \\
\hline & rs768454929 & agggtataaa & $\frac{\mathbf{a}}{\mathrm{c}}$ & agggeccaca & $\frac{1.5}{2.6}$ & $\downarrow$ & 7 & $10^{-6}$ & & \\
\hline & rs761695685 & gccagggtat & $\frac{\mathbf{a}}{g}$ & aaaagggccc & $\frac{1.5}{5.8}$ & $\downarrow$ & 19 & $10^{-6}$ & & \\
\hline & rs774326004 & ccagggtata & $\frac{\mathbf{a}}{t}$ & aaagggecca & $\frac{1.5}{0.9}$ & $\uparrow$ & 7 & $10^{-6}$ & \multirow{2}{*}{$\begin{array}{l}\text { (hypothetically) higher aggression of a mentally } \\
\text { unstable patient during growth hormone treatment so } \\
\text { that lithium (Li) and other antiaggression medication } \\
\text { may be required (a retrospective clinical case review) }\end{array}$} & \multirow{2}{*}{$\begin{array}{l}\text { [this work] } \\
{[70]}\end{array}$} \\
\hline & rs777003420 & aaggggccag & $\frac{\mathrm{g}}{t}$ & gtataaaaag & $\frac{1.5}{1.3}$ & $\uparrow$ & 3 & 0.05 & & \\
\hline \multirow[t]{2}{*}{ ILIB } & rs1143627 & ttttgaaagc & $\frac{c}{t}$ & ataaaaacag & $\frac{5}{2}$ & $\uparrow$ & 15 & $10^{-6}$ & $\begin{array}{l}\text { Greater body fat; gastric cancer, hepatocellular carcinoma, } \\
\text { non-small cell lung cancer, gastritis and gastric ulcer, } \\
\text { Graves' disease, major recurrent depression, and also, } \\
\text { (hypothetically) higher aggressiveness in patients who } \\
\text { receive cytokine immunotherapy (clinical retrospective review) } \\
\text { as well as Graves' disease and aggressiveness are } \\
\text { consequences of regular hemodialysis }\end{array}$ & $\begin{array}{l}\text { [77-83], [this } \\
\text { work] [84] } \\
{[85]}\end{array}$ \\
\hline & rs549858786 & tgaaagccat & $\frac{\mathrm{a}}{t}$ & aaaacagcga & $\frac{5}{6}$ & $\downarrow$ & 8 & $10^{-6}$ & $\begin{array}{l}\text { (hypothetically) less aggressive traits in patients who receive } \\
\text { cytokine immunotherapy or regular hemodialysis (clinical } \\
\text { retrospective review) }\end{array}$ & $\begin{array}{l}\text { [this } \\
\text { work],[84] }\end{array}$ \\
\hline
\end{tabular}

Notes: hereinafter, TBP, TATA-binding protein; TATA-box, the canonical TBP-binding site; $w \mathrm{t}$, ancestral allele; mut, minor allele; $\mathrm{K}_{\mathrm{D}}$, an estimate [52] of the dissociation constant $\left(\mathrm{K}_{\mathrm{D}}\right)$ of the TBP-DNA complex in vitro [53]; $\Delta$, the expression change in comparison with the norm: overexpression $(\uparrow)$, underexpression $(\downarrow)$, norm $(=) ; Z Z$-score; $a=1-p$, significance, where $p$ is probability (Fig. 1); TF, transcription factor; ALS, amyotrophic lateral sclerosis

drug during growth hormone treatment of mentally instable patients (Table 1).

Two base pairs away from a known biomedical marker (rs11568827), we found an unannotated SNP (rs796237787), which also represents a deletion of G. For this SNP, our Web service predicted the same change in the same TBP-binding site (Table 1). Therefore, we also propose rs796237787 as a candidate SNP marker of the same pathologies.

In addition, we found two unannotated SNPs (rs768454929, and rs761695685) that significantly damage the TBP-binding site in question, and thus reduce expression of the GH1 gene, as is the case for the known biomedical marker rs11568827. On this basis, we propose rs768454929 and rs761695685 as candidate SNP markers of the same disorders.

Finally, immediately upstream of the known biomedical marker rs11568827, we identified two unannotated SNPs (rs777003420 and rs774326004) for which our Web service predicted a significant increase in the affinity of TBP for the promoter of the GH1 gene, and accordingly, increased expression of this gene. That is why we propose rs777003420 and rs774326004 as candidate SNP markers associated with a higher dose of an additional antiaggression drug during growth hormone treatment of mentally instable patients.

The human IL1B gene (interleukin $1 \beta$ ) has an SNP marker (rs1143627) of a wide variety of human diseases such as Graves' disease [77], major recurrent depression [78], greater body fat in older men [79], non-small cell lung cancer [80], hepatocellular carcinoma [81], gastric cancer [82], gastric ulcer, and chronic gastritis [83] (Table 1). Previously, we experimentally verified in depth the predictions of our Web service $[51,52]$ for this SNP (rs1143627) by EMSA under both equilibrium [54] and nonequilibrium [55] conditions. First, our primary keyword search pinpointed a retrospective clinical review [84] about higher aggressiveness in patients who receive cytokine immunotherapy. Next, the secondary keyword search, produced a clinical case of regular hemodialysis that resulted in aggressiveness and Graves' disease at the same time [85]. Therefore, a human disease associated with the known SNP marker rs1143627 co-occurs with aggressiveness. For this reason, we predicted that this well-known biomedical SNP marker (rs1143627) can also be considered a candidate SNP marker of higher aggressiveness in patients receiving either cytokine immunotherapy or hemodialysis. 
Table 2 Candidate SNP markers of aggressiveness-related drug responses (these markers may significantly change the TBP-promoter affinity)

\begin{tabular}{|c|c|c|c|c|c|c|c|c|c|c|}
\hline \multirow[t]{2}{*}{ Gene } & \multirow{2}{*}{$\begin{array}{l}\text { dbSNP [12] } \\
\text { or see } \\
\text { [Reference] }\end{array}$} & \multirow[t]{2}{*}{$5^{\prime}$ flank } & \multirow[t]{2}{*}{$\frac{\mathrm{wt}}{\mathrm{mut}}$} & \multirow[t]{2}{*}{ 3' flank } & \multicolumn{2}{|c|}{$\mathrm{K}_{\mathrm{D}}, \mathrm{nM}$} & \multicolumn{2}{|c|}{ Z-score } & \multirow{2}{*}{$\begin{array}{l}\text { Known diseases (observations) [Reference] } \\
\text { or hypothetical ones in the case of the candidate } \\
\text { SNP markers predicted by us in [this work] } \\
\text { (see Methods: Additional file 2: Figure S1) }\end{array}$} & \multirow{2}{*}{$\begin{array}{l}\text { [Ref] or } \\
\text { [this work] }\end{array}$} \\
\hline & & & & & $\frac{w t}{m u t}$ & $\Delta$ & Z & $a$ & & \\
\hline SOD1 & rs7277748 & ggtctggect & $\frac{\mathbf{a}}{g}$ & taaagtagtc & $\frac{7}{2}$ & $\uparrow$ & 17 & $10^{-6}$ & $\begin{array}{l}\text { Familial amyotrophic lateral sclerosis (ALS), and also, } \\
\text { (hypothetically) aggressiveness is a memantine } \\
\text { response in Alzheimer's disease on the basis of this } \\
\text { drug's success in the case of ALS; aggressiveness } \\
\text { at late stages of either ALS or traumatic } \\
\text { encephalopathy [clinically similar to ALS]; lesser } \\
\text { male-male aggression (SOD1-deficient mouse males) }\end{array}$ & $\begin{array}{l}\text { [86], [this work] } \\
{[87-90]}\end{array}$ \\
\hline \multirow[t]{2}{*}{ StAR } & rs16887226 & cagccttcag & $\frac{c}{t}$ & gggggacatt & $\frac{10}{10}$ & $=$ & 1 & - & $\begin{array}{l}\text { Diabetic hypertension (unknown TF-binding site } \\
\text { damaged, not TATA box) }\end{array}$ & [91] \\
\hline & rs544850971 & tcagcggggg & $\frac{\mathbf{a}}{g}$ & catttaagac & $\frac{10}{12}$ & $\downarrow$ & 5 & $10^{-6}$ & $\begin{array}{l}\text { (hypothetically) lithium (Li) is a common drug against } \\
\text { aggressiveness, hypertension, and diabetes } \\
\text { (case reviews); old women on lipid-lowering medication } \\
\text { become more aggressive, hypertensive, and diabetic; } \\
\text { both diabetes and hypertension coexist with } \\
\text { aggressiveness in a magnesium (Mg) deficiency, in } \\
\text { intermittent explosive disorder, in Alzheimer's disease, } \\
\text { in postmenopausal women with multiple medical } \\
\text { problems in contrast to reduced aggressiveness } \\
\text { in old men regardless of disease and lesser } \\
\text { male aggression (a fish model on human behavior); } \\
\text { as well as coexistence of aggressiveness, hypertension, } \\
\text { and diabetes can elevate risk of nonfatal myocardial } \\
\text { infarction; diet has long-term impact on aggressiveness, } \\
\text { hypertension, and diabetes; aggressiveness, hypertension, } \\
\text { and diabetes are risk factors of cerebrovascular } \\
\text { disease, cerebral sclerosis; }\end{array}$ & $\begin{array}{l}\text { [this work] } \\
{[92-107]}\end{array}$ \\
\hline NOS2 & see [110] & gtataaatac & $\frac{\mathbf{t}}{c}$ & tcttggctgc & $\frac{2}{7}$ & $\uparrow$ & 3 & $10^{-2}$ & $\begin{array}{l}\text { Resistance to malaria, epilepsy risk, and also, } \\
\text { (hypothetically) drug-resistant or childhood epilepsy } \\
\text { is associated with aggressiveness; stigma as a critical } \\
\text { factor for interictal aggression in epilepsy } \\
\text { (clinical review); aggression, hyperactivity, and } \\
\text { impaired memory coexist during recurrent spontaneous } \\
\text { seizures in epilepsy (rat model), gender-biased complication } \\
\text { of excessive lead (Pb) intake manifested as lesser } \\
\text { exploration in females and higher aggressiveness } \\
\text { in males (mice) }\end{array}$ & $\begin{array}{l}{[108-110]} \\
{[\text { this work] }} \\
{[111][112-115]}\end{array}$ \\
\hline
\end{tabular}

Near this biomedical SNP marker rs1143627, we found the unannotated SNP rs549858786, which can significantly reduce the human $I L 1 B$ gene expression. That is why, rs1143627 may be a candidate SNP marker of lesser aggressiveness in patients undergoing either cytokine immunotherapy or hemodialysis.

\section{Candidate SNP markers of aggressiveness-related drug responses}

The human SOD1 gene (superoxide dismutase 1, synonym: $\mathrm{Cu} / \mathrm{Zn}$ superoxide dismutase): its promoter contains a known SNP marker (rs7277748) of familial amyotrophic lateral sclerosis (ALS) [86]: this SNP causes overexpression of this gene. Our primary keyword search yielded laboratory findings on higher intermale aggression in a murine model completely deficient in the SOD1 gene [87] (Table 2).
As for coexistence of aggressiveness and ALS, our secondary keyword search identified three articles on aggressiveness at late stages of ALS [88], in ALS with frontotemporal dysfunction [89], and in chronic traumatic encephalopathy whose signs and symptoms are clinically similar to those of ALS [89]. In addition, aggressiveness is a complication of the memantine-based treatment of Alzheimer's disease which was used due to success of the memantine-based treatment of ALS [90]. For all these reasons, we predicted that the known SNP marker rs7277748 can additionally be a candidate SNP marker of lesser male-male aggression, significant aggressiveness in ALS and in patients with Alzheimer's disease during memantine-based treatment.

The human StAR gene (steroidogenic acute regulatory protein, synonym: cholesterol trafficker) has a known SNP marker (rs544850971) of hypertension in diabetes [91] (Table 2). This SNP destroys a binding site for an 
Table 3 Candidate SNP markers of aggressiveness as a symptom of hereditary diseases (these markers may change the TBP-DNA affinity)

\begin{tabular}{|c|c|c|c|c|c|c|c|c|c|c|}
\hline \multirow[t]{2}{*}{ Gene } & \multirow{2}{*}{$\begin{array}{l}\text { dbSNP [12] } \\
\text { or see } \\
\text { [Reference] }\end{array}$} & \multirow[t]{2}{*}{$5^{\prime}$ flank } & \multirow[t]{2}{*}{$\frac{\mathrm{wt}}{\mathrm{mut}}$} & \multirow[t]{2}{*}{ 3' flank } & \multicolumn{2}{|c|}{$K_{D}, n M$} & \multicolumn{2}{|c|}{ Z-score } & \multirow{2}{*}{$\begin{array}{l}\text { Known diseases (observations) [Reference] or } \\
\text { hypothetical ones in the case of the candidate } \\
\text { SNP markers predicted by us in [this work] } \\
\text { (see Methods: Additional file 2: Figure S1) }\end{array}$} & \multirow[t]{2}{*}{ [Ref] or [this work] } \\
\hline & & & & & $\overline{\frac{w t}{m u t}}$ & $\bar{\Delta}$ & $\bar{Z}$ & $a$ & & \\
\hline \multirow[t]{2}{*}{$\overline{E S R 2}$} & rs35036378 & cctctcggtc & $\frac{\mathbf{t}}{9}$ & ttaaaaggaa & $\frac{6}{8}$ & $\downarrow$ & 5 & $10^{-3}$ & ESR2-deficient pT1 tumor, & [116] \\
\hline & rs766797386 & ttaaaaggaa & $\frac{\mathrm{g}}{t}$ & aaggggctta & $\frac{6}{7}$ & $\downarrow$ & 3 & $10^{-2}$ & $\begin{array}{l}\text { (hypothetically) ESR2-deficient maladaptive } \\
\text { aggressive social behaviors caused by bisphenol } \\
\text { A and phthalates in children (primary tumors } \\
\text { and aggression are well-known consequences } \\
\text { of environmental pollution with bisphenol A) }\end{array}$ & [this work] $[117,118]$ \\
\hline \multirow[t]{6}{*}{$H B B$} & rs397509430 & gggctgggca & $\underline{\mathrm{t}}$ & atacaacagt & $\frac{5}{29}$ & $\downarrow$ & 34 & $10^{-6}$ & \multirow{7}{*}{$\begin{array}{l}\text { Malaria resistance, thalassemia, and also } \\
\text { (hypothetically) thalassemia-related higher } \\
\text { male-male aggression, socialized aggression, } \\
\text { inattention, low IQ, acute psychosis with } \\
\text { aggression, impulsiveness as a form of } \\
\text { aggressiveness; aggression as a comorbidity } \\
\text { in 4-yo and 5-yo girls and in boys with } \\
\text { thalassemia in a hospital; aggressiveness } \\
\text { as a consequence of regular hemodialysis } \\
\text { in a severe form of thalassemia }\end{array}$} & \multirow{7}{*}{$\begin{array}{l}{[119] \text { [this work] }} \\
{[85,120-125]}\end{array}$} \\
\hline & rs33980857 & gggctgggca & $\frac{\mathbf{t}}{a, g, c}$ & atacaacagt & $\frac{5}{21}$ & $\downarrow$ & 27 & $10^{-6}$ & & \\
\hline & rs34598529 & ggctgggcat & $\frac{\mathbf{a}}{g}$ & aaagtcaggg & $\frac{5}{18}$ & $\downarrow$ & 24 & $10^{-6}$ & & \\
\hline & rs33931746 & gctgggcata & $\frac{\mathbf{a}}{g, c}$ & aagtcagggc & $\frac{5}{11}$ & $\downarrow$ & 14 & $10^{-6}$ & & \\
\hline & rs33981098 & agggctggge & $\frac{\mathbf{a}}{g, c}$ & taaaagtcag & $\frac{5}{9}$ & $\downarrow$ & 10 & $10^{-6}$ & & \\
\hline & rs34500389 & cagggctggg & $\frac{\mathbf{c}}{a, t, g}$ & ataaaagtca & $\frac{5}{6}$ & $\downarrow$ & 3 & $10^{-2}$ & & \\
\hline$(H B D)$ & rs35518301 & caggaccagc & $\frac{\mathbf{a}}{g}$ & taaaaggcag & $\frac{4}{8}$ & $\downarrow$ & 11 & $10^{-6}$ & & \\
\hline \multirow[t]{2}{*}{$H B B$} & rs63750953 & ctgggcataa & $\underline{\text { aa }}$ & gtcagggcag & $\frac{5}{8}$ & $\downarrow$ & 9 & $10^{-6}$ & \multirow{2}{*}{$\begin{array}{l}\text { (hypothetically)malaria resistance, thalassemia, } \\
\text { thalassemia-related higher male-male aggression, } \\
\text { socialized aggression, inattention, low IQ, acute }\end{array}$} & \multirow{3}{*}{$\begin{array}{l}\text { [this work] } \\
{[85,119,125]}\end{array}$} \\
\hline & rs 281864525 & tgggcataaa & $\frac{\mathbf{a}}{c}$ & gtcagggcag & $\frac{5}{7}$ & $\downarrow$ & 7 & $10^{-6}$ & & \\
\hline$(H B D)$ & rs34166473 & aggaccagca & $\frac{t}{c}$ & aaaaggcagg & $\frac{4}{8}$ & $\downarrow$ & 18 & $10^{-6}$ & $\begin{array}{l}\text { psychosis with aggression, impulsiveness as a } \\
\text { form of aggressiveness; aggression as a } \\
\text { comorbidity in 4-yo and 5-yo girls and in boys } \\
\text { with thalassemia in a hospital; aggressiveness } \\
\text { as a consequence of regular hemodialysis in a } \\
\text { severe form of thalassemia }\end{array}$ & \\
\hline
\end{tabular}

unknown transcription factor (not a TBP-binding site) and thereby causes underexpression of the human StARs gene. Here, using a primary keyword search, we found a laboratory finding of lesser male aggression in a StARdeficient fish model of human behavior [92]. In the case of our secondary keyword search, we found a number of articles [93-107] describing co-occurrence of aggressiveness, hypertension, and diabetes. As an example, old women on lipid-lowering medication become more aggressive and hypertensive and develop signs of diabetes [100]. Therefore, we propose the known SNP marker rs16887226 (hypertensive diabetes) as a candidate SNP marker of aggressiveness in many clinical and nonclinical cases listed in Table 2 .

Near the well-known biomedical SNP marker rs16887226, we found the unannotated SNP rs544850971. Next, we predicted using our Web service $[51,52]$ that this SNP can also cause underexpression of the human StAR gene, and, then, we proposed rs544850971 as a candidate SNP marker of the same diseases.

The human NOS2 gene (inducible nitric oxide synthase 2) contains an SNP marker of resistance to malaria [108] and epilepsy [109] where the $-51 \mathrm{~T} \rightarrow \mathrm{C}$ substitution (relative to the transcription start site of this gene [110]) causes NOS2 overexpression [108-110]. Our primary keyword search yielded laboratory data on a gender-biased complication of excessive lead $(\mathrm{Pb})$ intake (a murine model): lesser exploration in females and higher aggressiveness in males [111]. As for the secondary keyword search, it produced over 1,500 original articles on the co-occurrence of aggressiveness and epilepsy; here, we cite only the most interesting studies in our opinion. For example, both drug-resistant epilepsy and childhood epilepsy are associated with aggressiveness $[112,113]$ as well as a perceived stigma is a critical factor of interictal aggression, hyperactivity, and impaired memory during recurrent spontaneous seizures in epilepsy $[114,115]$. On this basis, we predicted that $51 \mathrm{~T} \rightarrow \mathrm{C}$ substitution within the known TATA-box of the human NOS2 gene can be a candidate SNP marker of higher aggressiveness in males under the influence of environmental pollution with $\mathrm{Pb}$ as one can see in (Table 2).

\section{Candidate SNP markers of aggressiveness as a symptom of hereditary diseases}

The human ESR2 gene (estrogen receptor $\beta$ ) promoter contains a known SNP marker (rs35036378) of a primary ESR2-deficient pT1 tumor whose development can lead to breast cancer without proper preventive treatment [116] (Table 3).

Using a primary keyword search, we uncovered a clinical case of maladaptive social behaviors (e.g., aggression) 
Table 4 Candidate SNP markers of obesity-related aggressiveness (these markers may change the TBP-promoter affinity)

\begin{tabular}{|c|c|c|c|c|c|c|c|c|c|c|}
\hline \multirow[t]{2}{*}{ Gene } & \multirow{2}{*}{$\begin{array}{l}\text { dbSNP [12] } \\
\text { or see } \\
\text { [Reference] }\end{array}$} & \multirow[t]{2}{*}{$5^{\prime}$ flank } & \multirow[t]{2}{*}{$\frac{w t}{m u t}$} & \multirow[t]{2}{*}{ 3' flank } & \multicolumn{2}{|c|}{$K_{D}, n M$} & \multicolumn{2}{|c|}{ Z-score } & \multirow{2}{*}{$\begin{array}{l}\text { Known diseases (observations) [Reference] or } \\
\text { hypothetical ones in the case of the candidate } \\
\text { SNP markers predicted by us in [this work] } \\
\text { (see Methods: Additional file 2: Figure S1) }\end{array}$} & \multirow{2}{*}{$\begin{array}{l}\text { [Ref] or } \\
\text { [this work] }\end{array}$} \\
\hline & & & & & $\frac{\mathrm{wt}}{m u t}$ & $\Delta$ & Z & $a$ & & \\
\hline$P G R$ & rs10895068 & gggagataaa & $\frac{\mathrm{g}}{a}$ & gagccgcgtg & $\frac{10}{6}$ & $\uparrow$ & 8 & $10^{-6}$ & $\begin{array}{l}\text { Endometrial cancer in obese women } \\
\text { [de novo pathogenic TATA box], and also } \\
\text { (hypothetically) obese school-aged girls } \\
\text { show verbal aggressiveness (e.g., victimization); } \\
\text { obese females are more aggressive } \\
\text { (primate model); obesity and aggression } \\
\text { coexist in polycystic ovary syndrome in women } \\
\text { with biliary calculi (retrospective clinical reviews); } \\
\text { high aggression/rejection in reproductive behavior } \\
\text { (mice); low attraction and high aggression } \\
\text { against males in females (rabbit model) }\end{array}$ & $\begin{array}{l}\text { [126], [this work] } \\
{[127-132]}\end{array}$ \\
\hline \multirow[t]{3}{*}{ LEP } & rs201381696 & tcgggecgct & $\frac{\mathbf{a}}{9}$ & taagagggge & $\frac{4}{12}$ & $\downarrow$ & 17 & $10^{-6}$ & $\begin{array}{l}\text { (hypothetically) obesity and also, in a } 10 \text { yo girl, } \\
\text { aggressiveness is a predictive factor for prevention } \\
\text { of obesity in adolescence with cardiovascular } \\
\text { complications in adulthood, as is the case for } \\
5 \text { yo boys (retrospective review); aberrant maternal } \\
\text { behavior, low aggression against an unknown } \\
\text { social stimulus and locomotor activity during } \\
\text { a high-fat diet (mice); low chance to be dominant } \\
\text { due to aggressiveness against subordinates in } \\
\text { female social behavior (macaques model), high } \\
\text { risks of suicidality, violence, and impulsive } \\
\text { aggressiveness in 19-45 yo patients with } \\
\text { schizophrenia; higher social aggressiveness in } \\
\text { males (rat model); longer survival in aggressive } \\
\text { leptin-deficient women with anorexia nervosa }\end{array}$ & $\begin{array}{l}\text { [this work], } \\
{[115,134-143]}\end{array}$ \\
\hline & rs200487063 & tgatcgggec & $\frac{\mathrm{g}}{a}$ & ctataagagg & $\frac{4}{2}$ & $\uparrow$ & 6 & $10^{-6}$ & \multirow[b]{2}{*}{$\begin{array}{l}\text { (hypothetically) obesity-caused hypertension, } \\
\text { and also, lower risk of aberrant maternal behavior, } \\
\text { higher aggression against an unknown social } \\
\text { stimulus, and locomotion activity on a high-fat diet } \\
\text { (mice); higher chance to be dominant due to } \\
\text { aggressiveness against subordinates in female } \\
\text { social behavior (macaque model); lower risks } \\
\text { of suicidality, violence, and impulsive } \\
\text { aggressiveness in 19-45 yo schizophrenic } \\
\text { patients; lower social aggressiveness in males } \\
\text { (rat model) }\end{array}$} & \multirow{2}{*}{$\begin{array}{l}\text { [this work] } \\
{[115,134-142]}\end{array}$} \\
\hline & rs34104384 & ccgctataag & $\frac{\mathbf{a}}{t}$ & ggggcgggca & $\frac{4}{3}$ & $\uparrow$ & 4 & $10^{-2}$ & & \\
\hline
\end{tabular}

caused by bisphenol A and phthalates in children [117]. Moreover, our secondary keyword search supported these striking findings by a retrospective clinical review showing that both primary tumors and aggression among the many behavioral disorders are well-known consequences of environmental pollution with bisphenol A [118]. With this in mind, we suggest the SNP marker rs35036378 (a primary ESR2-deficient pT1 tumor) as a candidate SNP marker of childhood aggressiveness caused by bisphenol A.

Near this biomedical SNP marker, we found an unannotated SNP (rs766797386) that can also reduce the human ESR2 gene expression as it was predicted by our Web service [51, 52]. Thus, we recommend to verify them as candidate SNP markers (rs766797386) of the above-mentioned human disorders.

The human $H B B$ and $H B D$ genes ( $\beta$ - and $\delta$-chains of hemoglobin, respectively) have the largest number of known SNP markers (rs34500389, rs33981098, rs33980857, rs34598529, rs33931746, rs397509430, and rs35518301) of resistance to malaria and thalassemia (Cooley's anemia) [119] (Table 3). According to output of a primary keyword search [120-122], a hemoglobin deficiency is associated with higher intermale aggression, socialized aggression, inattention, low IQ, acute psychosis with aggression, and also with aggression in 4- and 5-year-old girls. Similarly, our secondary keyword search showed that thalassemia increases the risk of aggressiveness (impulsiveness) $[123,124]$ and that aggressiveness is a comorbidity in hospitalized boys with thalassemia [125]. For these reasons, we nominate these biomedical SNP markers as candidate SNP markers of aggressiveness in Cooley's anemia.

Near these known SNP markers of hereditary diseases, we found three unannotated SNPs (rs63750953, rs281864525, and rs34166473) which can cause a hemoglobin deficiency in humans according to our Web service predictions. Thus, we propose them as candidate SNP markers of aggressiveness as a complication of thalassemia. 


\begin{tabular}{|c|c|c|}
\hline & & b \\
\hline $\begin{array}{r}\text { reference human genor } \\
\text { GRCh38(NCBI)/hg38(UC }\end{array}$ & $\begin{array}{l}\text { SNP TATA Comparator } \\
\text { Enter a GeneName [e.g BRCA2 or BRCA\%] or } \\
\text { Ensembl Gene ID [e.g. ENSG00000139618]: } \\
\text { GH1 } \\
\text { Search }\end{array}$ & $\begin{array}{l}\text { SNP TATA Comparator } \\
\text { Enter a GeneName [e.g BRCA2 or BRCA\%] or } \\
\text { Ensembl Gene ID [e.g. ENSG00000139618]: } \\
\text { GH1 } \\
\text { Search }\end{array}$ \\
\hline & $\begin{array}{l}\text { Genes: } \\
\text { Select a gene from list: } \\
\text { ENSG00000259384: GH1 } \\
\text { OSearch }\end{array}$ & $\begin{array}{l}\text { Genes: } \\
\text { Select a gene from list: } \\
\text { ENSG00000259384: GH1 : growth hor } \\
\text { Search }\end{array}$ \\
\hline & & $\begin{array}{l}\text { Transcripts: } \\
\text { Select a transcript from list: } \\
\end{array}$ \\
\hline & $\begin{array}{l}\text { ENSTO00000458650: GH1-003: : } 2010 \\
\text { ENSTO0000323322: GH1-001 : } 2010\end{array}$ & $\begin{array}{l}\text { ENST000000458650:GH1-003: : 2010 } \\
\text { ENST00000323322: GH1-001: : 2010: }\end{array}$ \\
\hline & ENST00000579711 : GH1-006 : : 2010! & ENST00000579711: GH1-006: : 2010: \\
\hline & $\begin{array}{l}\text { TSS: } 1 \\
{[-1000<\text { TSS }<+1000](+1 \text { default })}\end{array}$ & $\begin{array}{l}\text { TSS: } 1 \\
{[-1000<\text { TSS }<+1000](+1 \text { default })}\end{array}$ \\
\hline $\begin{array}{r}\text { the promo } \\
\text { alleles } 0 \\
\end{array}$ & $\begin{array}{l}\text { rs11568827 } \\
\text {-50G deleted }\end{array}$ & $\begin{array}{l}\text { GetSeq | } \\
\begin{array}{l}\text { Setuences } \\
\text { Base sequence: }\end{array} \quad-43 \mathrm{~A}=>\mathrm{C}\end{array}$ \\
\hline 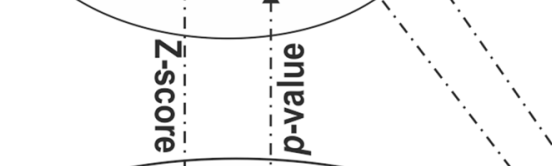 & & 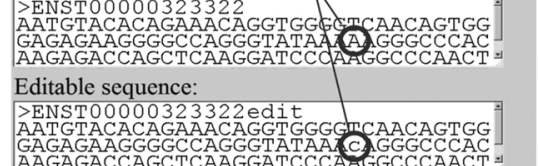 \\
\hline & & Calculate \\
\hline packá & 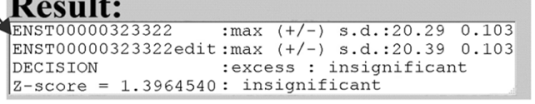 & 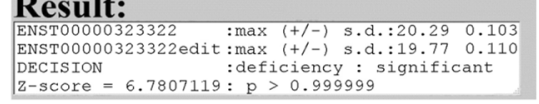 \\
\hline C & d & e \\
\hline$\underset{\text { Enter a GeneName }}{\text { SNe }} \mathbf{\text { TRRC }}$ & 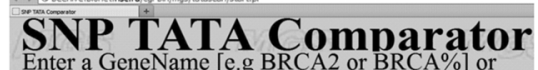 & 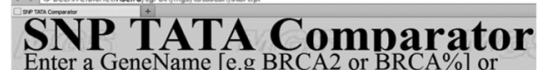 \\
\hline $\begin{array}{l}\text { Ensembl Gene ID [e.g. ENSGC } \\
\text { GH1 } \\
\text { Search }\end{array}$ & $\begin{array}{l}\text { Ensembl Gene ID [e.g. ENSG00000139618]: } \\
\text { GH1 } \\
\text { Search }\end{array}$ & $\begin{array}{l}\text { Ensembl Gene ID [e.g. ENSG00000139618]: } \\
\text { GH1 } \\
\text { Search }\end{array}$ \\
\hline $\begin{array}{l}\text { Genes: } \\
\text { Select a gene from list: }\end{array}$ & $\begin{array}{l}\text { Genes: } \\
\text { Select a gene from list: }\end{array}$ & $\begin{array}{l}\text { Genes: } \\
\text { Select a gene from list: }\end{array}$ \\
\hline $\begin{array}{l}\text { ENSG00000259384: GH1 : } \mathrm{c} \\
\text { Search | }\end{array}$ & $\begin{array}{l}\text { ENSG00000259384: GH1 : } 9 \\
\text { Search }\end{array}$ & $\begin{array}{l}\text { ENSG00000259384 : GH1 : growth hor } \\
\text { Search }\end{array}$ \\
\hline $\begin{array}{l}\text { Transcripts: } \\
\text { Select a transcript from list: }\end{array}$ & $\begin{array}{l}\text { Transcripts: } \\
\text { Select a transcript from list: }\end{array}$ & $\begin{array}{l}\text { Transcripts: } \\
\text { Select a transcript from list: }\end{array}$ \\
\hline ENST00000458650: GH1-003 & ENSTO0000458650: GH1-003: : 20105 & ENST00000458650: GH1-003: : 2010s \\
\hline ENST00000323322 : GH1-001 : : 2010 & ENST00000323322 : GH1-001 : : 2010 & 3322 : GH1-001 : : 2010 \\
\hline ENST00000579711 : GH1-006 : : 2010! & ENST00000579711 : GH1-006 : : 2010! & ENST00000579711: GH1-006: : 2010! \\
\hline TSS: 1 & TSS: 1 & TSS: 1 \\
\hline$[-1000<\mathrm{TSS}<+1000](+1$ default $)$ & {$[-1000<$ TSS $<+1000](+1$ default $)$} & {$[-1000<$ TSS $<+1000](+1$ default $)$} \\
\hline rs761695685 & rs774326004 & rs777003420 \\
\hline $\begin{array}{l}\text { Sequences } \\
\text { Base sequen }\end{array}$ & $\begin{array}{l}\text { Sequences } \\
\text { Base sequence: }\end{array}$ & $\begin{array}{l}\text { Sequences } \\
\text { Base sequence }\end{array}$ \\
\hline 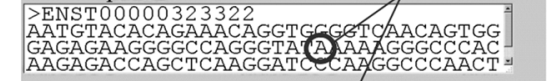 & 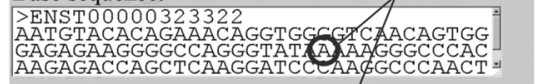 & 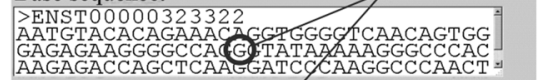 \\
\hline 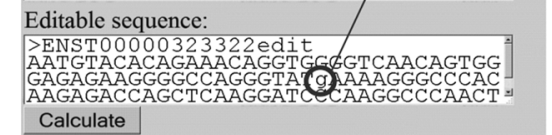 & 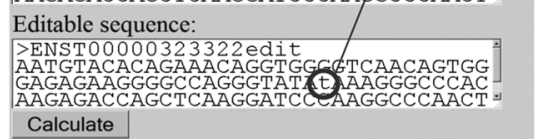 & 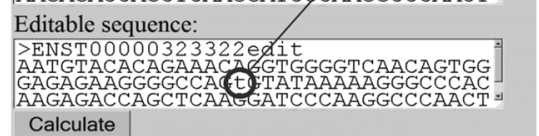 \\
\hline 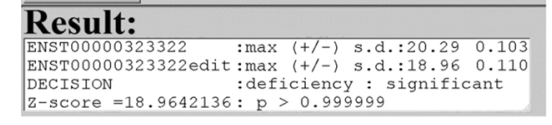 & 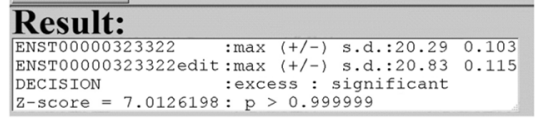 & 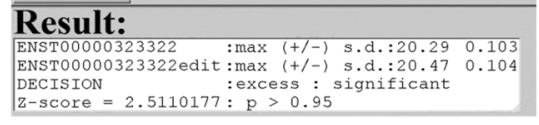 \\
\hline \multicolumn{3}{|c|}{$\begin{array}{l}\text { Fig. } 1 \text { The result produced by SNP_TATA_Comparator [51, 52] for aggressiveness-related SNP markers of the human GH1 gene. a rs } 11568827, \mathbf{b} \\
\text { rs768454929, } \mathbf{c} \text { rs761695685, d rs774326004, and e rs777003420. Solid, dotted, and dashed arrows denote BioPerl queries [145] to the reference } \\
\text { human genome. Dash-and-dot arrows indicate statistical significance estimates for the alteration of gene expression by the minor allele (in com- } \\
\text { parison with the ancestral allele) using the R package [150]. Circles indicate the alleles marked by their dbSNP ID [12] }\end{array}$} \\
\hline
\end{tabular}


Candidate SNP markers of obesity-related aggressiveness The human PGR gene (progesterone receptor) has the biomedical SNP marker rs10895068 of endometrial cancer in obese women [126] caused by this gene's overexpression (Table 4).

Our primary keyword search retrieved the laboratory findings about female reproductive behavior where the progesterone receptor excess increases aggression toward/rejection of males in a murine model [127] and aggression against males in a rabbit model [128]. As for our secondary keyword search, it produced a large number of articles showing co-occurrence of aggressiveness and obesity in women [129-132]. For instance, obese school-aged girls are predisposed to verbal aggressiveness (e.g., victimization) [129]; in addition, obesity and aggression coexist in polycystic ovary syndrome [131] and in women with biliary calculi [132]. Accordingly, we predict rs10895068 to be a candidate SNP marker of gender-biased aggressiveness in obese women.

The human $L E P$ gene (leptin; synonyms: obesity factor with acronym $O B$ ) contains a candidate SNP marker (rs201381696) of obesity (reducing this gene's expression) as well as candidate SNP markers (rs200487063 and rs34104384) of obesity-induced hypertension caused by overexpression of this gene as we have predicted in silico and verified in vitro in our previous work [66] (Table 4).

In this work, we experimentally confirmed (in cell culture) the rs200487063-caused deficient expression of the LEP gene using the pGL 4.10 vector (the reporter gene LUC for luciferase; see Methods: Cell culture, transfection, and reporter assays) whose expression can be seen in Fig. 2.

This figure shows that the rs200487063-caused significant downregulation of reporter gene $L U C$ is approximately twofold in both cell lines: HCT116 (human colon adenocarcinoma exemplifying basal expression of the human LEP gene) and MCF-7 (carcinoma of the human mammary gland epithelium exemplifying tissue-specific expression of this gene), at $\alpha<0.05$ according to Student's $t$-test (asterisks in Fig. 2). As one can see in Fig. 2, there are no differences in the effects of this candidate SNP marker (rs200487063) between the basal and tissue-specific mode of the human $L E P$ gene expression in our study, in agreement with a well-known independent experiment on multiple promoter models [133].

That is why we then conducted our primary keyword search for publications associating aggressiveness with a significant deficiency in this gene's expression; this search produced a large number of research papers and review articles on this topic $[115,134-143]$. As an example, our secondary keyword search identified a retrospective review [135] showing that high aggressiveness in 10-year-old girls is a statistically significant predictive factor of obesity in adolescence $(p<0.0005)$ and cardiovascular complications in adulthood; the same is true for

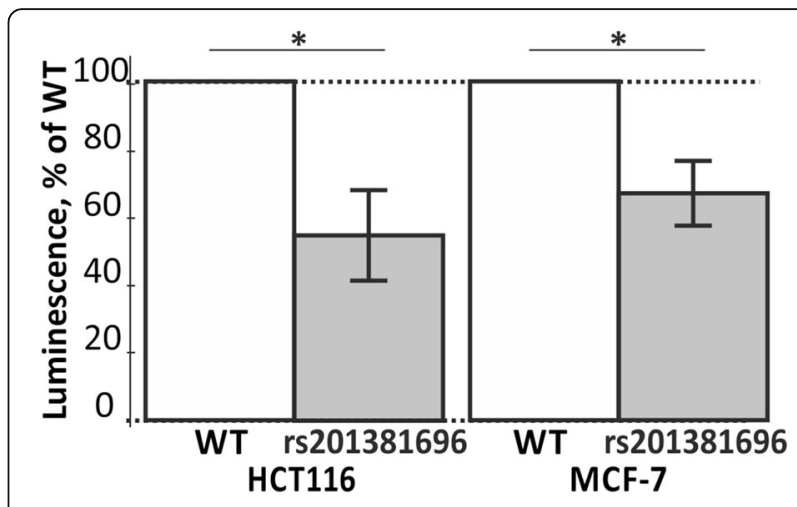

Fig. 2 Cell culture verification of the candidate SNP marker rs201381696 in human cell lines transfected with the PGL 4.10 vector carnying a reporter LUC gene. Open bars, ancestral allele (wild type, WT); gray bars, minor allele; HCT116, a human colon adenocarcinoma cell line as an example of basal expression of the human LEP gene; MCF-7, a cell line of the human mammary gland epithelium carcinoma as an example of tissue-specific expression of this gene. The height of the gray bars and their error bars correspond to the mean estimates and their standard deviations calculated from at least three independent measurements. Asterisks indicate a statistically significant difference at the confidence level $a<0.05$

5-year-old boys. Furthermore, a leptin deficiency in a murine model causes aberrant maternal behavior, lower aggression against an unknown social stimulus, and increased locomotor activity during a high-fat diet [136]. In addition, a clinical case review [143] revealed longer survival in aggressive leptin-deficient women with anorexia nervosa. On the basis of these data, we expanded our prediction [66] on the obesity-related candidate SNP markers rs201381696, rs200487063, and rs34104384 to our prognosis that these SNPs can also be candidate SNP markers of aggressiveness in obesity.

\section{Discussion}

Because the TBP-binding site is one of the best-studied regulatory sequences within the human genome [48], we limited our research to SNPs altering the human gene expression via statistically significant changes in the TATA-binding protein's affinity for human gene promoters. Using our Web service SNP_TATA_Comparator $[51,52]$, we analyzed 493 SNPs located within $[-70 ;-20]$ proximal promoter regions of 33 human genes and found only 28 aggressiveness-related candidate SNP markers (6\%). Each of them can alter expression of one of 10 human genes via significant changes in the TBP-binding affinity of promoters of these genes, as we deduced from our results shown in Tables 1, 2, 3 and 4. This finding does not mean that the other 465 of the 493 SNPs (94\%, data not shown) cannot be considered aggressivenessrelated candidate SNP markers; they may at least alter transcription factor-binding sites (e.g., rs11568827, rs796237787, and rs16887226). To conduct this kind of 
analysis for any of them, one can find a number of public Web services [22-39] for in-depth studies on other molecular mechanisms behind the effects of SNPs on human health; these services' research capabilities can be enhanced when they are used together with our Web service SNP_TATA_Comparator $[51,52]$.

It should be emphasized that known SNP markers of monogenic diseases cause these diseases, whereas candidate SNP markers of polygenic diseases whose symptoms include aggressiveness can only serve as genomewide informative landmarks suggestive of either increased or decreased risk of aggressiveness (in these diseases relative to the norm) among patients with the minor alleles of these SNPs [67]. For example, here we predicted a candidate SNP marker (rs201381696) of aggressiveness in obesity. Using this whole-genome landmark, parents of an aggressive 10-year-old girl with a minor allele of rs201381696 may choose a diet and a physical exercise regimen for their daughter to prevent her obesity in adolescence and cardiovascular complications in adulthood; the same approach is applicable to 5-year-old boys. Similarly, using our suggested candidate SNP marker (rs1143627) of higher aggressiveness in patients receiving cytokine immunotherapy, a physician can prescribe an antiaggression medication together with cytokine immunotherapy to a patient carrying a minor allele of this SNP. In addition, according to our prediction of the candidate SNP marker (rs35036378) of childhood aggressiveness caused by bisphenol A, parents may look into the presence of this compound in plastic toys of their child if he/she has the minor allele of this SNP. Furthermore, using the candidate SNP marker of higher aggressiveness in males subjected to environmental pollution with $\mathrm{Pb}$ [the $-51 \mathrm{~T} \rightarrow \mathrm{C}$ substitution in the human NOS2 gene promoter], people with a minor allele of this SNP can modify their lifestyle to minimize their contact with materials containing lead.

In this study, we encountered a huge number of clinical cases, retrospective reviews, research articles, laboratory data, and empirical findings-on aggressiveness in various life situations-from clinicians, pharmacists, physiologists, geneticists, psychologists, bioinformaticians, pedagogues, sociologists, legal scholars, economists, and other relevant experts such as specialists on insurance, management, health care, law enforcement, and environmental protection. The gigantic scale, multidisciplinary nature, complexity, and disarray of this information pool may hinder the use of this vital knowledge for broad practical applications in the general population. As shown in Tables 1, 2, 3 and 4, candidate SNP markers of aggressiveness seem to be promising whole-genome landmarks around which researchers can organize existing knowledge about this integral characteristic of the genome as a whole; this characteristic reflects the individual mobilization potential of the human body. The usable portions of this knowledge may be directly applicable to people carrying a minor allele of such SNPs.

Finally, each aggressiveness-related candidate SNP marker predicted in this work needs comprehensive verification under various in vitro and in vivo experimental conditions, as well as in clinical protocols involving representative cohorts of patients with the corresponding diseases and healthy volunteers (as a control). After that, such SNP markers will become practically applicable. To facilitate the validation, for each predicted candidate SNP marker we show a quantitative parameter: the equilibrium dissociation constant $\left(K_{d}\right)$ for binding of human TATA-binding protein to 26-bp synthetic duplex DNA identical to the SNP in question (as the prediction of our Web service, expressed in "nanomoles per liter" units, nM; Tables 1, 2, 3 and 4). These additional data are intended for optimization of experimental and clinical conditions during verification of our predictions before their practical use.

\section{Conclusions}

If these aggressiveness-related candidate SNP markers are validated by clinical protocols, these whole-genome landmarks may become useful for physicians (may help to optimize treatment of patients) as well as for the general population (may help to choose a lifestyle preventing aggressiveness-related comorbidities and complications).

\section{Methods}

Cell culture, transfection, and reporter assays

Cell lines HCT116 (human colon adenocarcinoma) and MCF-7 (carcinoma of the human mammary gland epithelium) were cultivated in a complete medium consisting of Dulbecco's modified Eagle's medium/Nutrient mixture F-12 Ham, supplemented with $10 \%(\mathrm{v} / \mathrm{v})$ of fetal bovine serum (Sigma) and penicillin $(100 \mathrm{U} / \mathrm{mL})$ and streptomycin $(100 \mathrm{mg} / \mathrm{mL})$ (BioloT). The cultures were maintained at $37^{\circ} \mathrm{C}$ in a humidified atmosphere containing $5 \%$ of $\mathrm{CO}_{2}$ until the desired level of confluence. All the experiments were performed at $80-85 \%$ confluence. Oligonucleotides corresponding to ancestral and minor alleles of the predicted candidate SNP marker rs201381696 (Table 4) were cloned into the pGL 4.10 vector (Promega, USA) and cotransfected with pRL-TK using Screen Fect A (InCella) as described by Wolfe and the colleagues [144]. After that, the cells were cultured in 6-well plates for $24 \mathrm{~h}$. Luciferase activity was measured by means of the Dual-Luciferase Reporter Assay kit (Promega).

\section{DNA sequence analysis in silico}

We analyzed DNA sequences of the human gene promoters retrieved from the human reference genome 
using the standard BioPerl library [145] via our Web service [51, 52], (Fig. 1) in the case of ancestral alleles of SNPs that were analyzed and those manually corrected on the basis of the description of these alleles from the database dbSNP [12]. For each DNA sequence, we calculated the maximal value and its standard deviation $-\ln \left(\mathrm{K}_{\mathrm{D}}^{0}\right) \pm \delta$ of the affinity of TBP for the $[-70 ;-20]$ promoter region (where all the known sites are located) using our Web service $[51,52]$ as described in Additional file 1 [146-150].

\section{Keyword search within the NCBI databases}

For each case of predicted significant overexpression or underexpression of the human genes (as clinically relevant biochemical markers), we conducted a manual two-step keyword search in the NCBI databases [151] as described in detail elsewhere [152] and as depicted schematically in Additional file 2: Figure S1. In this figure, two boxes consisting of a dashed line depict the primary keyword search for diseases whose symptoms include aggressiveness and whose known biochemical markers correspond to the gene expression alteration caused by the SNP being considered.

In addition, in Additional file 2: Figure S1, there is a box outlined with a dotted line that depicts the secondary keyword search for co-occurrence of the aggressiveness-related disease found by the primary keyword search and the hereditary disease clinically associated with this SNP. Our heuristic interpretation of each aggressiveness-related candidate SNP marker in accordance with a significant alteration of expression of a human gene is listed in the second rightmost column of Tables 1, 2, 3 and 4; the supporting information consisting of clinical cases, retrospective reviews, empirical data, laboratory observations, and published hypotheses are cited in the rightmost column.

\section{Additional files}

Additional file 1: Supplementary method. A quantitative sequencebased prediction of binding affinity of TATA-binding protein (TBP) for a human gene promoter. (PDF $161 \mathrm{~kb}$ )

Additional file 2: Figure S1. A flow chart of the keyword search for aggressiveness-related diseases whose biochemical markers correspond to an alteration in expression of the human gene under study containing the candidate SNP marker of interest. Legend: two boxes consisting of a dashed line depict the primary keyword search for diseases whose symptoms include aggressiveness; the box outlined with a dotted line depicts the secondary keyword search for co-occurrence of the aggressiveness-related disease found by the primary keyword search and the hereditary disease clinically associated with the SNP in question. (PNG 385 kb)

\section{Abbreviations}

ALS: Amyotrophic lateral sclerosis; EMSA: Electrophoretic mobility shift assay; $\mathrm{K}_{\mathrm{d}}$ : Equilibrium dissociation constant; In: Natural logarithm; mut: Minor allele of SNPS; SNP: Single nucleotide polymorphism; TBP: TATA-binding protein; TF: Transcription factor; TSS: Transcription start site; WT: Wild type (norm)

\section{Acknowledgments}

We are grateful to Shevchuk Editing (Brooklyn, NY, USA; URL: http://www.shevchukediting.com) for English translation and editing.

\section{Declarations}

This article has been published as part of BMC Genetics Vol 17 Suppl 14, 2016: Selected articles from BGRSISB-2016: genomics. The full contents of the supplement are available online at http://bmcgenomics.biomedcentral.com/ articles/supplements/volume-17-supplement-14

\section{Funding}

Data compilation and analysis were supported by grant 14-04-00485 from the Russian Foundation for Basic Research to LKS, EBS, TVA, EVK, and OVA. The writing of the manuscript was supported by grant 14.B25.31.0033 from the government of the Russian Federation (Resolution 220) to MPP. DAR acknowledges the support of the software development by the Russian Science Foundation (http://rscf.ru/en/), project 14-24-00123. IVC received support for interpretation of computer-based prediction outputs in terms of aggressive behavior from the Russian Science Foundation, project 14-14-00269. MYM acknowledges support for the human cell culture experiments from the Russian Foundation for Basic Research, grant 15-0405780. NPB and NAK received support for the manuscript correction in response to the reviewers' comments from project 0324-2015-0003 of the Russian Government Budget. The Russian Science Foundation has funded publication of this article. No funding bodies had any role in study design, data collection and analysis, decision to publish, or preparation of the manuscript.

\section{Availability of data and material}

Not applicable.

\section{Authors' contributions}

MPP wrote the manuscript and coordinated the computational research. IVC interpreted the computer-based predictions and helped to draft the manuscript. EBS and TVA compiled the data. DAR designed, developed, maintained, adapted, and tuned the software for both sequence and data analysis. PMP designed and performed the sequence analysis. EBS, EVK, OVA, MYM, and NPB conducted the cell culture experiments. LKS coordinated the empirical research. NAK conceived of and supervised the study. All the coauthors read and approved the final version of the manuscript.

\section{Competing interests}

The authors declare that they have no competing interests.

\section{Consent for publication}

Not applicable.

\section{Ethics approval and consent to participate}

Not applicable.

\section{Author details}

${ }^{1}$ Institute of Cytology and Genetics, Siberian Branch of Russian Academy of Sciences, 10 Lavrentyev Avenue, Novosibirsk 630090, Russia. ${ }^{2}$ Novosibirsk State University, 2 Pirogova Street, Novosibirsk 630090, Russia. ${ }^{3}$ Children's Hospital Los Angeles, 4640 Hollywood Boulevard, University of Southern California, Los Angeles, CA 90027, USA. ${ }^{4}$ Vector-Best Inc, Koltsovo, Novosibirsk Region 630559, Russia.

Published: 28 December 2016

References

1. Lorenz K. On Aggression. Hove: Psychology Press; 2002.

2. Eldakar OT, Gallup AC. The group-level consequences of sexual conflict in multigroup populations. PLoS One. 2011;6:e26451.

3. de Almeida RM, Cabral JC, Narvaes R. Behavioural, hormonal and neurobiological mechanisms of aggressive behaviour in human and nonhuman primates. Physiol Behav. 2015;143:121-35.

4. Anderson CA, Bushman BJ. Human aggression. Annu Rev Psychol. 2002;53: 27-51.

5. Miczek KA, Fish EW, De Bold JF, De Almeida RM. Social and neural determinants of aggressive behavior: pharmacotherapeutic targets at serotonin, dopamine and gamma-aminobutyric acid systems. Psychopharmacology (Berl). 2002;163:434-58. 
6. Baron RA, Richardson DR. Human Aggression. London: Plenum Pres; 1994

7. Siegel A, Bhatt S, Bhatt R, Zalcman SS. The neurobiological bases for development of pharmacological treatments of aggressive disorders. Curr Neuropharmacol. 2007;5:135-47.

8. Benus RF, Koolhaas JM, van Oortmerssen GA. Individual differences in behavior reaction to a changing environment in mice and rat. Behav. 1987;100:105-22.

9. Ehrman L, Parsons PA. Behavior genetics and evolution. New York: McGrawHill; 1981.

10. Zapata I, Serpell JA, Alvarez CE. Genetic mapping of canine fear and aggression. BMC Genomics. 2016;17:572.

11. Colonna V, Ayub Q, Chen Y, Pagani L, Luisi P, Pybus M, et al. Human genomic regions with exceptionally high levels of population differentiation identified from 911 whole-genome sequences. Genome Biol. 2014;15:R88.

12. Sherry ST, Ward MH, Kholodov M, Baker J, Phan L, Smigielski EM, et al. dbSNP. the NCBI database of genetic variation. Nucleic Acids Res. 2001;29:308-11.

13. Zerbino DR, Wilder SP, Johnson N, Juettemann T, Flicek PR. The Ensembl regulatory build. Genome Biol. 2015;16:56.

14. Haeussler M, Raney BJ, Hinrichs AS, Clawson H, Zweig AS, Karolchik D, et al. Navigating protected genomics data with UCSC Genome Browser in a Box. Bioinformatics. 2015;31:764-6.

15. Kemmeren P, Sameith K, van de Pasch LA, Benschop JJ, Lenstra TL, Margaritis $T$, et al. Large-scale genetic perturbations reveal regulatory networks and an abundance of gene-specific repressors. Cell. 2014;157:740-52.

16. Aprile G, Bonotto M, Ongaro E, Pozzo C, Giuliani F. Critical appraisal of ramucirumab (IMC-1121B) for cancer treatment: from benchside to clinical use. Drugs. 2013;73:2003-15.

17. Mallal S, Nolan D, Witt C, Masel G, Martin AM, Moore C, et al. Association between presence of HLA-B 5701, HLA-DR7, and HLA-DQ3 and hypersensitivity to HIV-1 reverse-transcriptase inhibitor abacavir. Lancet. 2002;359:727-32.

18. Trovato GM. Sustainable medical research by effective and comprehensive medical skills: overcoming the frontiers by predictive, preventive and personalized medicine. EPMA J. 2014:5:14.

19. Yoo SS, Jin C, Jung DK, Choi YY, Choi JE, Lee WK, et al. Putative functional variants of XRCC1 identified by RegulomeDB were not associated with lung cancer risk in a Korean population. Cancer Genet. 2015;208:19-24.

20. Vasiliev GV, Merkulov VM, Kobzev VF, Merkulova TI, Ponomarenko MP, Kolchanov NA. Point mutations within 663-666 bp of intron 6 of the human TDO2 gene, associated with a number of psychiatric disorders, damage the YY-1 transcription factor binding site. FEBS Lett. 1999;462:85-8.

21. Ponomarenko JV, Orlova GV, Merkulova TI, Gorshkova EV, Fokin ON, Vasiliev GV, et al. rSNP_Guide: an integrated database-tools system for studying SNPs and site-directed mutations in transcription factor binding sites. Hum Mutat. 2002;20:239-48.

22. Chen CY, Chang IS, Hsiung CA, Wasserman WW. On the identification of potential regulatory variants within genome wide association candidate SNP sets. BMC Med Genomics. 2014;7:34.

23. Macintyre G, Bailey J, Haviv I, Kowalczyk A. is-rSNP: a novel technique for in silico regulatory SNP detection. Bioinformatics. 2010;26:524-30.

24. Ponomarenko JV, Furman DP, Frolov AS, Podkolodny NL, Orlova GV, Ponomarenko MP, et al. ACTIVITY: a database on DNA/RNA sites activity adapted to apply sequence-activity relationships from one system to another. Nucleic Acids Res. 2001;29:284-7.

25. Boyle AP, Hong EL, Hariharan M, Cheng Y, Schaub MA, Kasowski M, et al. Annotation of functional variation in personal genomes using RegulomeDB. Genome Res. 2012:22:1790-7.

26. Riva A. Large-scale computational identification of regulatory SNPs with ISNP-MAPPER. BMC Genomics. 2012:13:S7.

27. Ponomarenko JV, Orlova GV, Frolov AS, Gelfand MS, Ponomarenko MP. SELEX_DB: a database on in vitro selected oligomers adapted for recognizing natural sites and for analyzing both SNPs and site-directed mutagenesis data. Nucleic Acids Res. 2002;30:195-9.

28. Andersen $M C$, Engstrom PG, Lithwick $S$, Arenillas D, Eriksson P, Lenhard $B$, et al. In silico detection of sequence variations modifying transcriptional regulation. PLoS Comput Biol. 2008;4:e5.

29. Fu Y, Liu Z, Lou S, Bedford J, Mu XJ, Yip KY, et al. FunSeq2: a framework for prioritizing noncoding regulatory variants in cancer. Genome Biol. 2014;15:480.

30. Chen CC, Xiao S, Xie D, Cao X, Song CX, Wang T, et al. Understanding variation in transcription factor binding by modeling transcription factor genome-epigenome interactions. PLoS Comput Biol. 2013;9:e1003367.

31. Deyneko IV, Kalybaeva YM, Kel AE, Blocker H. Human-chimpanzee promoter comparisons: property-conserved evolution? Genomics. 2010;96:129-33.
32. Bryzgalov LO, Antontseva EV, Matveeva MY, Shilov AG, Kashina EV, Mordvinov VA, et al. Detection of regulatory SNPs in human genome using ChIP-seq ENCODE data. PLoS One. 2013;8:e78833.

33. Johnson AD, Handsaker RE, Pulit SL, Nizzari MM, O'Donnell CJ, de Bakker PI. SNAP: a web-based tool for identification and annotation of proxy SNPS using HapMap. Bioinformatics. 2008;24:2938-9.

34. Coetzee SG, Rhie SK, Berman BP, Coetzee GA, Noushmehr H. FunciSNP: an R/bioconductor tool integrating functional non-coding data sets with genetic association studies to identify candidate regulatory SNPs. Nucleic Acids Res. 2012;40:e139.

35. Podkolodnyy NL, Afonnikov DA, Vaskin YY, Bryzgalov LO, Ivanisenko VA, Demenkov PS, et al. Program complex SNP-MED for analysis of singlenucleotide polymorphism (SNP) effects on the function of genes associated with socially significant diseases. Russ J Genet App Res. 2014;4:159-67.

36. Saccone SF, Bolze R, Thomas P, Quan J, Mehta G, Deelman E, et al. SPOT: a web-based tool for using biological databases to prioritize SNPs after a genome-wide association study. Nucleic Acids Res. 2010;38:W201-9.

37. Rasskazov DA, Antontseva EV, Bryzgalov LO, Matveeva MY, Kashina EV, Ponomarenko PM, et al. rSNP_Guide-based evaluation of SNPs in promoters of the human APC and MLH1 genes associated with colon cancer. Russ J Genet App Res. 2014;4:245-53.

38. Deyneko IV, Bredohl B, Wesely D, Kalybaeva YM, Kel AE, Blocker H, et al. FeatureScan: revealing property-dependent similarity of nucleotide sequences. Nucleic Acids Res. 2006;34:W591-5.

39. Barenboim M, Manke T. ChroMoS: an integrated web tool for SNP classification, prioritization and functional interpretation. Bioinformatics. 2013;29:2197-8.

40. Ni Y, Hall AW, Battenhouse A, lyer VR. Simultaneous SNP identification and assessment of allele-specific bias from ChIP-seq data. BMC Genet. 2012;13:46.

41. Leschner S, Deyneko IV, Lienenklaus S, Wolf K, Bloecker H, Bumann D, et al. Identification of tumor-specific Salmonella Typhimurium promoters and their regulatory logic. Nucleic Acids Res. 2012;40:2984-94

42. Hu J, Locasale JW, Bielas JH, O'Sullivan J, Sheahan K, Cantley LC, et al. Heterogeneity of tumor-induced gene expression changes in the human metabolic network. Nat Biotechnol. 2013;31:522-9.

43. Hein $\mathrm{M}$, Graver $\mathrm{S}$. Tumor cell response to bevacizumab single agent therapy in vitro. Cancer Cell Int. 2013:13:94.

44. Ponomarenko MP, Ponomarenko JV, Frolov AS, Podkolodnaya OA, Vorobyev DG, Kolchanov NA, et al. Oligonucleotide frequency matrices addressed to recognizing functional DNA sites. Bioinformatics. 1999;15:631-43.

45. Amberger J, Bocchini CA, Scott AF, Hamosh A. McKusick's Online Mendelian Inheritance in Man (OMIM). Nucleic Acids Res. 2009;37:D793-6.

46. Mitsuyasu H, Izuhara K, Mao XQ, Gao PS, Arinobu Y, Enomoto T, et al. lle50Val variant of IL4R-alpha upregulates IgE synthesis and associates with atopic asthma. Nat Genet. 1998;19:119-20.

47. Savinkova LK, Ponomarenko MP, Ponomarenko PM, Drachkova IA, Lysova MV, Arshinova TV, et al. TATA box polymorphisms in human gene promoters and associated hereditary pathologies. Biochemistry (Mosc). 2009;74:117-29.

48. Ponomarenko M, Mironova V, Gunbin K, Savinkova L. Hogness Box. In: Maloy S, Hughes K, editors. Brenner's Encyclopedia of Genetics, vol. 3. 2nd ed. San Diego: Academic Press, Elsevier Inc; 2013. p. 491-4.

49. Martianov I, Viville S, Davidson I. RNA polymerase II transcription in murine cells lacking the TATA binding protein. Science. 2002;298:1036-9.

50. Muller F, Lakatos L, Dantonel J, Strahle U, Tora L. TBP is not universally required for zygotic RNA polymerase II transcription in zebrafish. Curr Biol. 2001;11:282-7.

51. Rasskazov DA, Gunbin KV, Ponomarenko PM, Vishnevsky OV, Ponomarenko MP, Afonnikov DA. SNP_TATA_comparator: Web-service for comparison of SNPs within gene promoters associated with human diseases using the equilibrium equation of the TBP/TATA complex. Vavilov J Genet Breed. 2013;17:599-606.

52. Ponomarenko M, Rasskazov D, Arkova O, Ponomarenko P, Suslov $V$, Savinkova L, et al. How to use SNP_TATA_Comparator to find a significant change in gene expression caused by the regulatory SNP of this gene's promoter via a change in affinity of the TATA-binding protein for this promoter. Biomed Res Int. 2015;2015:359835.

53. Ponomarenko PM, Savinkova LK, Drachkova IA, Lysova MV, Arshinova TV, Ponomarenko MP, et al. A step-by-step model of TBP/TATA box binding allows predicting human hereditary diseases by single nucleotide polymorphism. Dokl Biochem Biophys. 2008;419:88-92.

54. Savinkova L, Drachkova I, Arshinova T, Ponomarenko P, Ponomarenko M, Kolchanov N. An experimental verification of the predicted effects of 
promoter TATA-box polymorphisms associated with human diseases on interactions between the TATA boxes and TATA-binding protein. PLoS One. 2013;8:e54626

55. Drachkova I, Savinkova L, Arshinova T, Ponomarenko M, Peltek S, Kolchanov N. The mechanism by which TATA-box polymorphisms associated with human hereditary diseases influence interactions with the TATA-binding protein. Hum Mutat. 2014;35:601-8.

56. Drachkova IA, Shekhovtsov SV, Peltek SE, Ponomarenko PM, Arshinova TV, Ponomarenko MP, et al. Surface plasmon resonance study of the interaction between the human TATA-box binding protein and the TATA element of the NOS2A gene promoter. Vavilov J Genet Breed. 2012;16:391-6.

57. Arkova OV, Kuznetsov NA, Fedorova OS, Kolchanov NA, Savinkova LK. Realtime interaction between TBP and the TATA box of the human triosephosphate isomerase gene promoter in the norm and pathology. Acta Naturae. 2014:6:36-40

58. Ponomarenko PM, Ponomarenko MP, Drachkova IA, Lysova MV, Arshinova $T V$, Savinkova LK, et al. Prediction of the affinity of the TATA-binding protein to TATA boxes with single nucleotide polymorphisms. Mol Biol (Mosk) 2009:43:327-36.

59. Drachkova IA, Ponomarenko PM, Arshinova TV, Ponomarenko MP, Suslov W, Savinkova LK, et al. In vitro examining the existing prognoses how TBP binds to TATA with SNP associated with human diseases. Health. 2011;3:577-83.

60. Ponomarenko PM, Suslov W, Savinkova LK, Ponomarenko MP, Kolchanov NA. A precise equation of equilibrium of four steps of TBP binding with the TATA box for prognosis of phenotypic manifestation of mutations. Biofizika. 2010;55:400-14.

61. Suslov W, Ponomarenko PM, Efimov VM, Savinkova LK, Ponomarenko MP Kolchanov NA. SNPs in the HIV-1 TATA box and the AIDS pandemic. J Bioinform Comput Biol. 2010;8:607-25.

62. Mironova W, Omelyanchuk NA, Ponomarenko PM, Ponomarenko MP, Kolchanov NA. Specific/nonspecific binding of TBP to promoter DNA of the auxin response factor genes in plants correlated with ARFs function on gene transcription (activator/repressor). Dokl Biochem Biophys. 2010:433:191-6.

63. Ponomarenko PM, Ponomarenko MP. Sequence-based prediction of transcription up-regulation by auxin in plants. J Bioinform Comput Biol. 2015;13:1540009

64. Suslov W, Ponomarenko PM, Ponomarenko MP, Drachkova IA, Arshinova TV Savinkova LK, et al. TATA box polymorphisms in genes of commercial and laboratory animals and plants associated with selectively valuable traits. Russ J Genet. 2010;46:394-403.

65. Ponomarenko MP, Suslov W, Gunbin KV, Ponomarenko PM, Vishnevsky OV, Kolchanov NA. Identification of the relationship between the variability of the expression of signaling pathway genes in the human brain and the affinity of TATA-binding protein to their promoters. Russ J Genet App Res. 2015;5. in press.

66. Arkova OV, Ponomarenko MP, Rasskazov DA, Drachkova IA, Arshinova TV, Ponomarenko PM, et al. Obesity-related known and candidate SNP markers can significantly change affinity of TATA-binding protein for human gene promoters. BMC Genomics. 2015:16:S5.

67. Ponomarenko MP, Arkova O, Rasskazov D, Ponomarenko P, Savinkova L, Kolchanov N. Candidate SNP markers of gender-biased autoimmune complications of monogenic diseases are predicted by a significant change in the affinity of TATAbinding protein for human gene promoters. Front Immunol. 2016;7:130

68. Ponomarenko P, Rasskazov D, Suslov V, Sharypova E, Savinkova L, Podkolodnaya O, et al. Candidate SNP markers of chronopathologies are predicted by a significant change in the affinity of TATA-binding protein for human gene promoters. Biomed Res Int. 2016;2016. in press.

69. Horan M, Millar DS, Hedderich J, Lewis G, Newsway V, Mo N, et al. Human growth hormone $1(\mathrm{GH} 1)$ gene expression: complex haplotype-dependent influence of polymorphic variation in the proximal promoter and locus control region. Hum Mutat. 2003;21:408-23.

70. Ji NY, Findling RL. Pharmacotherapy for mental health problems in people with intellectual disability. Curr Opin Psychiatry. 2016;29:103-25

71. Poisson A, Nicolas A, Sanlaville D, Cochat P, De Leersnyder H, Rigard C, et al. Smith-Magenis syndrome is an association of behavioral and sleep/wake circadian rhythm disorders. Arch Pediatr. 2015;22:638-45.

72. Blanco-Barca O, Gallego-Blanco M, Ruiz-Ponte C, Barros-Angueira F, EsqueteLopez C, Eiris-Punal J, et al. Smith-Magenis syndrome: a report of two new cases and an approximation to their characteristic behavioural phenotype. Rev Neurol. 2004;38:1038-42

73. Huber RS, Houlihan D, Filter K. Dubowitz syndrome: a review and implications for cognitive, behavioral, and psychological features. J Clin Med Res. 2011;3:147-55.
74. White SM, Morgan A, Da Costa A, Lacombe D, Knight SJ, Houlston R, et al. The phenotype of Floating-Harbor syndrome in 10 patients. Am J Med Genet A. 2010;152A:821-9.

75. Downey J, Ehrhardt AA, Morishima A, Bell JJ, Gruen R. Gender role development in two clinical syndromes: Turner syndrome versus constitutional short stature. J Am Acad Child Adolesc Psychiatry. 1987;26:566-73.

76. Turnaev II, Rasskazov DA, Arkova OV, Ponomarenko MP, Ponomarenko PM, Savinkova LK, et al. Hypothetical SNP markers that significantly affect the affinity of the TATA-binding protein to VEGFA, ERBB2, IGF1R, FLT1, KDR, and MET oncogene promoters as chemotherapy targets. Mol Biol (Mosk). 2016;50:161-73.

77. Hayashi F, Watanabe M, Nanba T, Inoue N, Akamizu T, Iwatani Y. Association of the $-31 C / T$ functional polymorphism in the interleukin-1 beta gene with the intractability of Graves' disease and the proportion of T helper type 17 cells. Clin Exp Immunol. 2009;158:281-6.

78. Borkowska P, Kucia K, Rzezniczek S, Paul-Samojedny M, Kowalczyk M, Owczarek A, et al. Interleukin-1 beta promoter (-31T/C and -511C/T) polymorphisms in major recurrent depression. J Mol Neurosci. 2011;44:12-6.

79. Strandberg L, Mellstrom D, Ljunggren O, Grundberg E, Karlsson MK, Holmberg AH, et al. IL6 and IL1B polymorphisms are associated with fat mass in older men: the MrOS Study Sweden. Obesity (Silver Spring). 2008; 16:710-3.

80. Wu KS, Zhou X, Zheng F, Xu XQ, Lin YH, Yang J. Influence of interleukin-1 beta genetic polymorphism, smoking and alcohol drinking on the risk of non-small cell lung cancer. Clin Chim Acta. 2010;411:1441-6.

81. Wang $Y$, Kato N, Hoshida $Y$, Yoshida H, Taniguchi H, Goto $T$, et al. Interleukin-1 beta gene polymorphisms associated with hepatocellular carcinoma in hepatitis C virus infection. Hepatology. 2003;37:65-71.

82. El-Omar EM, Carrington M, Chow WH, McColl KE, Bream JH, Young HA, et al Interleukin-1 polymorphisms associated with increased risk of gastric cancer. Nature. 2000:404:398-402.

83. Martinez-Carrillo DN, Garza-Gonzalez E, Betancourt-Linares R, MonicoManzano T, Antunez-Rivera C, Roman-Roman A, et al. Association of IL1B -511C/-31T haplotype and Helicobacter pylori vacA genotypes with gastric ulcer and chronic gastritis. BMC Gastroenterol. 2010;10:126.

84. Pesce $M$, Speranza L, Franceschelli S, lalenti $V$, Patruno A, Febo MA, et al. Biological role of interleukin-1 beta in defensive-aggressive behaviour. J Biol Regul Homeost Agents. 2011;25:323-9.

85. Boubaker K, Ounissi M, Khiari K, Harzallah A, Abbes M, El Younsi F, et al. A rare case of Graves' disease in a patient on regular haemodialysis. Nephro Ther. 2010:6:251-4.

86. Niemann S, Broom WJ, Brown Jr RH. Analysis of a genetic defect in the TATA box of the SOD1 gene in a patient with familial amyotrophic latera sclerosis. Muscle Nerve. 2007:36:704-7.

87. Garratt M, Brooks RC. A genetic reduction in antioxidant function causes elevated aggression in mice. J Exp Biol. 2015;218:223-7.

88. Marconi A, Meloni G, Fossati F, Lunetta C, Bastianello S, Melazzini M, et al. Aggressiveness, sexuality, and obsessiveness in late stages of ALS patients and their effects on caregivers. Amyotroph Lateral Scler. 2012;13:452-8.

89. Stern RA, Riley DO, Daneshvar DH, Nowinski CJ, Cantu RC, McKee AC. Longterm consequences of repetitive brain trauma: chronic traumatic encephalopathy. PM R. 2011:3:S460-7.

90. Prokselj T, Jerin A, Kogoj A. Memantine may affect pseudobulbar affect in patients with Alzheimer's disease. Acta Neuropsychiatr. 2013:25:361-6.

91. Casal AJ, Sinclair VJ, Capponi AM, Nicod J, Huynh-Do U, Ferrari P. A novel mutation in the steroidogenic acute regulatory protein gene promoter leading to reduced promoter activity. J Mol Endocrinol. 2006;37:71-80.

92. Huffman LS, Mitchell MM, O'Connell LA, Hofmann HA. Rising StARs: behavioral, hormonal, and molecular responses to social challenge and opportunity. Horm Behav. 2012;61:631-41.

93. Tilov B, Semerdzhieva M, Bakova D, Tornyova B, Stoyanov D. Study of the relationship between aggression and chronic diseases (diabetes and hypertension). J Eval Clin Pract. 2016;22:421-4.

94. McCloskey MS, Kleabir K, Berman ME, Chen EY, Coccaro EF. Unhealthy aggression: intermittent explosive disorder and adverse physical health outcomes. Health Psychol. 2010;29:324-32.

95. Treiber KA, Lyketsos CG, Corcoran C, Steinberg M, Norton M, Green RC, et al. Vascular factors and risk for neuropsychiatric symptoms in Alzheimer's disease: the Cache County Study. Int Psychogeriatr. 2008;20:538-53.

96. Lahad A, Heckbert SR, Patrick DL, Psaty BM. Hostility, aggression and the association with hypertension in post-menopausal women. J Hum Hypertens. 1996;10:S115-21. 
97. Alexopoulos GS, Jeste DV, Chung H, Carpenter D, Ross R, Docherty JP. The expert consensus guideline series. Treatment of dementia and its behavioral disturbances. Introduction: methods, commentary, and summary. Postgrad Med. 2005;(Spec No):6-22.

98. Drayton S, Canter A, Allen C. Dilemmas in providing patient-focused care. CANNT J. 2003:13:30-3.

99. Cohen PG. Aromatase, adiposity, aging and disease. The hypogonadal-metabolicatherogenic-disease and aging connection. Med Hypotheses. 2001;56:702-8.

100. Johnson S. The multifaceted and widespread pathology of magnesium deficiency. Med Hypotheses. 2001;56:163-70.

101. Olson MB, Kelsey SF, Matthews KA, Bairey Merz CN, Eteiba W, McGorray SP, et al. Lipid-lowering medication use and aggression scores in women: a report from the NHLBI-sponsored WISE study. J Womens Health (Larchmt). 2008;17:187-94.

102. Cole SR, Kawachi I, Liu S, Gaziano JM, Manson JE, Buring JE, et al. Time urgency and risk of non-fatal myocardial infarction. Int J Epidemiol. 2001;30:363-9.

103. Rogers PJ. A healthy body, a healthy mind: long-term impact of diet on mood and cognitive function. Proc Nutr Soc. 2001;60:135-43.

104. Matsumoto Y, Uyama O, Shimizu S, Michishita H, Mori R, Owada T, et al. Do anger and aggression affect carotid atherosclerosis? Stroke. 1993;24:983-6.

105. Gianturco DT, Breslin MS, Heyman A, Gentry WD, Jenkins CD, Kaplan B. Personality patterns and life stress in ischemic cerebrovascular disease. 1. Psychiatric findings. Stroke. 1974;5:453-60.

106. Mumenthaler M. Cerebral sclerosis. Diagnostic criteria and differential diagnostic consideration in practice. Schweiz Med Wochenschr. 1975;105:353-61.

107. Voors AW. Does lithium depletion cause atherosclerotic heart-disease? Lancet. 1969;2:1337-9.

108. Clark IA, Rockett KA, Burgner D. Genes, nitric oxide and malaria in African children. Trends Parasitol. 2003;19:335-7.

109. Gonzalez-Martinez JA, Moddel G, Ying Z, Prayson RA, Bingaman WE, Najm IM. Neuronal nitric oxide synthase expression in resected epileptic dysplastic neocortex. J Neurosurg. 2009:110:343-9.

110. Burgner D, Rockett $K$, Ackerman H, Hull J, Usen S, Pinder M, Kwiatkowski DP. Haplotypic relationship between SNP and microsatellite markers at the NOS2A locus in two populations. Genes Immun. 2003;4:506-14.

111. Kasten-Jolly J, Pabello N, Bolivar VJ, Lawrence DA. Developmental lead effects on behavior and brain gene expression in male and female BALB/ cAnNTac mice. Neurotoxicology. 2012:33:1005-20.

112. Benedetti-Isaac JC, Torres-Zambrano M, Vargas-Toscano A, Perea-Castro E, Alcala-Cerra G, Furlanetti LL, et al. Seizure frequency reduction after posteromedial hypothalamus deep brain stimulation in drug-resistant epilepsy associated with intractable aggressive behavior. Epilepsia. 2015;56:1152-61.

113. Abubakar A, Kariuki SM, Tumaini JD, Gona J, Katana K, Owen JA, et al. Community perceptions of developmental and behavioral problems experienced by children living with epilepsy on the Kenyan coast: A qualitative study. Epilepsy Behav. 2015;45:74-8.

114. Seo JG, Kim JM, Park SP. Perceived stigma is a critical factor for interictal aggression in people with epilepsy. Seizure. 2015;26:26-31.

115. Obeid M, Frank J, Medina M, Finckbone V, Bliss R, Bista B, et al. Neuroprotective effects of leptin following kainic acid-induced status epilepticus. Epilepsy Behav. 2010;19:278-83.

116. Philips S, Richter A, Oesterreich S, Rae JM, Flockhart DA, Perumal NB, et al. Functional characterization of a genetic polymorphism in the promoter of the ESR2 gene. Horm Cancer. 2012;3:37-43.

117. Rosenfeld CS. Bisphenol A and phthalate endocrine disruption of parental and social behaviors. Front Neurosci. 2015;9:57.

118. Peluso ME, Munnia A, Ceppi M. Bisphenol-A exposures and behavioural aberrations: median and linear spline and meta-regression analyses of 12 toxicity studies in rodents. Toxicology. 2014;325:200-8.

119. Martiney JA, Cerami A, Slater AF. Inhibition of hemozoin formation in Plasmodium falciparum trophozoite extracts by heme analogs: possible implication in the resistance to malaria conferred by the beta-thalassemia trait. Mol Med. 1996;2:236-46.

120. Miller BA. TRPC2. Handb Exp Pharmacol. 2014:222:53-65.

121. Mubarak A, Fadel W, Said S, Hammar MA. Profile of Behavior and IQ in Anemic Children. CNS Spectr. 2010;15:631-8

122. Johnson SR, Winkleby MA, Boyce WT, McLaughlin R, Broadwin R, Goldman L. The association between hemoglobin and behavior problems in a sample of low-income Hispanic preschool children. J Dev Behav Pediatr. 1992;13:209-14.

123. Namazi MR. Minor thalassemia may be a risk factor for impulsiveness. Med Hypotheses. 2003;60:335-6.
124. Guasco G, La Mantia A, Cuniolo A. Psychological problems of thalassemic subjects. Pediatr Med Chir. 1987;9:269-79.

125. Guasco G, Gamalero PC, Cuniolo A. Psychological problems of thalassemic subjects. Pediatr Med Chir. 1985;7:271-8.

126. De Vivo I, Huggins GS, Hankinson SE, Lescault PJ, Boezen M, Colditz GA, et al. A functional polymorphism in the promoter of the progesterone receptor gene associated with endometrial cancer risk. Proc Natl Acad Sci U S A. 2002;99:12263-8.

127. Frye CA, Walf AA, Kohtz AS, Zhu Y. Progesterone-facilitated lordosis of estradiol-primed mice is attenuated by knocking down expression of membrane progestin receptors in the midbrain. Steroids. 2014;81:17-25.

128. Hoffman KL, Martínez-Alvarez E, Rueda-Morales RI. The inhibition of female rabbit sexual behavior by progesterone: progesterone receptor-dependent and -independent effects. Horm Behav. 2009;55:84-92.

129. Liu X, Chen G, Yan J, Luo J. Weight status and bullying behaviors among Chinese school-aged children. Child Abuse Negl. 2016;52:11-9.

130. Shively CA, Register TC, Clarkson TB. Social stress, visceral obesity, and coronary artery atherosclerosis in female primates. Obesity (Silver Spring). 2009;17:1513-20.

131. Elsenbruch S, Hahn S, Kowalsky D, Offner AH, Schedlowski M, Mann K, et al. Quality of life, psychosocial well-being, and sexual satisfaction in women with polycystic ovary syndrome. J Clin Endocrinol Metab. 2003;88:5801-7.

132. Geissler P. Psychosomatic aspects of gallstones. A test psychological study of female gallstone patients with clinical symptoms in comparison with a psychoanalytic study of gallstones. Z Psychosom Med Psychoanal. 1981;27:263-74.

133. Mogno I, Vallania F, Mitra RD, Cohen BA. TATA is a modular component of synthetic promoters. Genome Res. 2010;20:1391-7.

134. Lee EB, Mattson MP. The neuropathology of obesity: insights from human disease. Acta Neuropathol. 2014;127:3-28.

135. Louise S, Warrington NM, McCaskie PA, Oddy WH, Zubrick SR, Hands B, et al Associations between aggressive behaviour scores and cardiovascular risk factors in childhood. Pediatr Obes. 2012;7:319-28.

136. Bellisario V, Panetta P, Balsevich G, Baumann V, Noble J, Raggi C, et al. Maternal high-fat diet acts as a stressor increasing maternal glucocorticoids' signaling to the fetus and disrupting maternal behavior and brain activation in C57BL/6J mice. Psychoneuroendocrinology. 2015;60:138-50.

137. Michopoulos $V$, Higgins M, Toufexis D, Wilson ME. Social subordination produces distinct stress-related phenotypes in female rhesus monkeys. Psychoneuroendocrinology. 2012;37:1071-85.

138. Atmaca M, Kuloglu M, Tezcan E, Ustundag B. Serum leptin and cholestero levels in schizophrenic patients with and without suicide attempts. Acta Psychiatr Scand. 2003;108:208-14

139. Atmaca M, Kuloglu M, Tezcan E, Ustundag B. Serum leptin and cholesterol values in violent and non-violent suicide attempters. Psychiatry Res. 2008;158:87-91.

140. Tamashiro KL, Nguyen MM, Fujikawa T, Xu T, Yun Ma L, Woods SC, et al. Metabolic and endocrine consequences of social stress in a visible burrow system. Physiol Behav. 2004:80:683-93.

141. Tumer N, Erdos B, Matheny M, Cudykier I, Scarpace PJ. Leptin antagonist reverses hypertension caused by leptin overexpression, but fails to normalize obesity-related hypertension. J Hypertens. 2007:25:2471-8.

142. Beltowski J. Central vs. peripheral leptin excess in the pathogenesis of obesity-associated hypertension. J Hypertens. 2008:26:827-8.

143. Smiarowska M, Krzyzanowska-Swiniarska B, Kaminski R, Szakowska E, Horodnicki J. Some hormones secretion and personality in anorexia nervosa syndrome. Psychiatr Pol. 2002;36:83-93.

144. Wolfe A, Kim HH, Tobet S, Stafford DE, Radovick S. Identification of a discrete promoter region of the human GnRH gene that is sufficient for directing neuron-specific expression: a role for POU homeodomain transcription factors. Mol Endocrinol. 2002:16:435-49.

145. Stajich JE, Block D, Boulez K, Brenner SE, Chervitz SA, Dagdigian C, et al. The Bioperl toolkit: Perl modules for the life sciences. Genome Res. 2002;12:1611-8

146. Bucher P. Weight matrix descriptions of four eukaryotic RNA polymerase II promoter elements derived from 502 unrelated promoter sequences. J Mol Biol. 1990:212:563-78.

147. Karas H, Knuppel R, Schulz W, Sklenar H, Wingender E. Combining structural analysis of DNA with search routines for the detection of transcription regulatory elements. Comput Appl Biosci. 1996;12:441-6. 
148. Ponomarenko MP, Ponomarenko JV, Frolov AS, Podkolodny NL, Savinkova $\mathrm{LK}$, Kolchanov NA, et al. Identification of sequence-dependent DNA features correlating to activity of DNA sites interacting with proteins. Bioinformatics. 1999;15:687-703.

149. Sokolenko AA, Sandomirskii II, Savinkova LK. Interaction of yeast TATA-binding protein with short promotor segments. Mol Biol (Mosk). 1996;30:279-85.

150. Waardenberg AJ, Basset SD, Bouveret R, Harvey RP. CompGO: an R package for comparing and visualizing Gene Ontology enrichment differences between DNA binding experiments. BMC Bioinformatics. 2015;16:275.

151. NCBI Resource Coordinators. Database resources of the National Center for Biotechnology Information. Nucleic Acids Res. 2015;43:D6-17.

152. Missala I, Kassner U, Steinhagen-Thiessen E. A systematic literature review of the association of lipoprotein(a) and autoimmune diseases and atherosclerosis. Int J Rheumatol. 2012;2012:480784.

Submit your next manuscript to BioMed Central and we will help you at every step:

- We accept pre-submission inquiries

- Our selector tool helps you to find the most relevant journal

- We provide round the clock customer support

- Convenient online submission

- Thorough peer review

- Inclusion in PubMed and all major indexing services

- Maximum visibility for your research

Submit your manuscript at www.biomedcentral.com/submit
Biomed Central 